\title{
Affective variables as predictors of biology achievement: A study on $11^{\text {th }}$ grade students
}

\author{
Ayten Alpmen ${ }^{1 \mathrm{a}}$ \\ ${ }^{1}$ Patnos Vocational and Technical Anatolian High School, Ağr1 04500 Turkey
}

\begin{abstract}
The purpose of this study was to examine the contribution of the gender, self-efficacy beliefs, task value, and learning strategies to the 11 th grade students' biology achievement. A total of 1035 students from different high schools in Yenimahalle and Çankaya districts of Ankara participated in the study. The Motivated Strategies for Learning Questionnaire [21], (MSLQ) and Biology Achievement Test (BAT) were used to collect data. Results of the the simultaneous multiple regression analysis indicated that 11 th grade students' gender, task values, selfefficacies and elaboration learning strategies were statistically significant predictors of their Biology achievement; whereas rehearsal and organization learning strategies were not.
\end{abstract}

Keywords: biology achievement; self-efficacy; task value; learning strategies

\section{Introduction}

How students learn is a complex concept to be explained by teachers, researchers, and also for students. According to Gabel, [20] the behaviors that students show in the learning environments are influenced by the values the students hold, the motivation or beliefs they have, and the attitudes they have about school, science, and life in general. Therefore, for a better explanation on how students learn, not only cognitive; but also the affective variables should be considered, [55], [63]. These and other contextual variables should be considered to acquire a level of conclusion for interpreting and proposing new perspectives about the effectiveness of curricula, instruction, and education in general.

\subsection{Social cognitive theory}

Social cognitive theory, proposed primarily by Albert Bandura, mainly stated that human learning is affected by both internal and external factors, [3], [5], [6]. Based on this theory, it was stressed that due to its being constituted in a social environment, meaningful learning is also a social event, [50]. Therefore understanding human learning requires taking both

\footnotetext{
${ }^{a}$ Corresponding author: aytenalpmen@gmail.com
} 
the social and psychological factors into account; rather than just focusing on the quality of the information given, [5].

\subsection{Self-Efficacy}

By Bandura's introduction of social cognitive theory in 1970s, the term self-efficacy was also put forth as a core feature of this theory. Based on a simplistic aspect of the theory, self-efficacy is defined as the individuals' own beliefs on fulfilling a task at a suitable level of accomplishment, [2].

Higher levels of self-efficacy are found to be related with students' achievement levels, [1], [5], [24], [27], [28], [33], [34], [35], [36], [37], [41], [42], [43], [44], [49], [50], [51], $[53],[66],[71],[73]$. It was also proposed that self-efficacy is a strong predictor of students' higher achievement, [8], [37], [41], [42], [46].

\subsection{Task value}

Based on the initial model developed by Eccles, Adler, Futterman, Goff, Kaczala, Meece, \& Midgley, [14] the expectancy-value model of achievement motivation described how students' beliefs and values affect their behaviors on achievement. In this theory, task values are defined as individual's general understanding of a specific task as defining it in terms of being useful, joyful, and satisfactory, [15], [65], [66].

It was found that, students with higher achievement hold more specific task values, [11], [16], [19], [65], [71] [72]. Also task values are found to be strong predictors of students' achievement, [11], [19], [66], [71].

\subsection{Learning strategies}

Pintrich, [39] stated that learning strategies are the special ways influencing individuals' control over own cognition. Students' use of proper learning strategies are reported to be one of the major determinants of their successful achievement, [23], [38], [41], [60], [71], [75].

\subsection{Gender}

Students' achievement is influenced by various cognitive and affective variables, as well as by their genders, [38]. For Lenon, [30] there are no significant gender differences in the mean of individuals' science achievement. On the other hand, females are reported to achive higher than males in science/biology in some studies, [29], [34], [61]. There are also other studies emphasizing that males posses an overal advantage in science/biology achievement, [25], [57].

\subsection{Purpose}

The purpose of this study was to investigate whether self-efficacy beliefs, task value, learning strategies, and gender difference can be used to predict 11 grade students' Biology achievement. 


\subsection{Research question}

How well do the students' rehearsal, organization and elaboration learning strategies, task value, and self-efficacy beliefs and gender differences predict 11 grade students' Biology achievement?

\section{Method}

The study possessed a correlational research design. To fulfill the aim of the study, the data were analyzed using simultaneous regression analysis.

\subsection{Participants}

The sample of the study, which was shaped through utilizing convenience sampling method, consisted of 1035 11th grade high school students in Yenimahalle and Cankaya regions of Ankara.

\subsection{Data collection instruments}

There were two main data collection instruments used in the study. One of them was the Turkish version of the Motivated Strategies for the Learning Questionnaire (MSLQ) measuring students' learning strategies and their motivational orientations. The second one was the Biology Achievement Test (BAT) used for determining students' Biology achievement.

\subsubsection{The Turkishversion of the motivated strategies for the learning questionnaire (MSLQ)}

The Motivated Strategies for Learning Questionnaire (MSLQ) is a self-report 7 point rating scale consisting of 81 items; developed by Pintrich, Smith, Garcia, and McKeachie, [45] and adapted into Turkish by Sungur, [58]. This questionnaire consisted of two main parts; which namely were motivation with 6 sub-scales $(31$ items) and learning strategies with 9 subscales (50 items).In the present study, five subscales of the questionnaire were used as rehearsal (REH), organization (ORG), elaboration (ELA), self-efficacy beliefs (SE) and task value beliefs (TV).

In the present study, the value of Cronbach's alpha for task value was found to be .91 and for self-efficacy .94. In terms of the learning strategies scale, the values of Cronbach's alpha for rehearsal, elaboration and organization were found to be $.84, .87$, and .83, respectively.

\subsubsection{The biology achievement test (BAT)}

The study assessed the biology achievement of students by the help of a multiple choice test named Biology Achievement Test (BAT).The test was consisting of 20 multiple choice questions chosen from the previous University Entrance Examinations (ÖSS) between the years 1999-2006 and the reliability (Cronbach's alpha) of the test was found to be .70. 


\section{Results}

\subsection{Descriptive statistics}

According to the descriptive statistics obtained from the data, the BAT scores of the students have a mean of 59.99 over 100 points; therefore, it can be said that the students in this study showed moderate achievement level. Additionally, results showed that rehearsal $(\mathrm{M}=4.47)$, organization $(\mathrm{M}=4.33)$, and elaboration $(\mathrm{M}=4.14)$ are the most frequently used learning strategies in biology learning, respectively. Male students $(\mathrm{M}=63.72)$ showed higher achievement than females $(M=56.54)$ in the mean of the BAT scores obtained in this study. On the other hand, the means of task value and self-efficacy beliefs also indicated that female students are prone to have higher self-efficacy beliefs $(M=4.69)$, whereas males posses higher task values $(\mathrm{M}=4.91)$ on biology.

\subsection{Simultaneous linear regression analysis}

In this study, simultaneous linear regression analysis was used to investigate the predictive power of independent variables on the dependent variable. According to the results obtained from the data, it was primarily found that 11th grade students' gender $(\mathrm{t}=-4.316)$, elaboration learning strategy $(\mathrm{t}=2.62)$, self-efficacy $(\mathrm{t}=2.095)$ and task values $(\mathrm{t}=5.65)$ are significant correlates of their biology achievement; whereas rehearsal $(\mathrm{t}=-1.061)$ and organization $(\mathrm{t}=.210)$ learning strategies are not $(\rho<.05)$. Based on the semi-partial coreelations obtained from the data being a male student, using elaboration learning strategies and possessing higher task values and self-efficacies are related with achieving higher in 11th grade biology lessons. Additionally, rehearsal and organization learning strategies are found not to be significantly related with 11th grade students' biology achievement. Results also revealed that, the independent variables significantly explained the $\% 16.5$ of the variation in students' Biology achievement $(\mathrm{R}=.406, \mathrm{~F}(6,1028)=9.95$, $\mathrm{p}<.05)$. Results also showed that gender $(\beta=-.128)$, elaboration $(\beta=.100)$, self-efficacy $(\beta=.087)$ and task value $(\beta=.241)$ significantly contributed to 11 th grade students' Biology achievement $(\rho<.05)$. On the other hand, organization $(\beta=.008)$ and rehearsal $(\beta=-.036)$ learning strategies did not make statistically significant contributions $(\rho<.05)$. Based on the beta coefficients, task value is found to be the strongest predictor of 11 th grade students' Biology achievement, while all other variables are controlled $(\beta=.241)$.

Table 1. Summary of the simultaneous regression analysis

\begin{tabular}{lcccc}
\hline Independent variables & $\mathrm{B}$ & $\mathrm{SE}$ & $\mathrm{Beta}(\beta)$ & $\mathrm{t}$ \\
\hline Gender & -5.100 & 1,182 & -.128 & $-4.316^{*}$ \\
Rehearsal & -.486 &, 458 & -.036 & -1.061 \\
Organization & .113 &, 536 & .008 & .210 \\
Elaboration & 1.442 &, 550 & .100 & $2.620^{*}$ \\
Self-efficacy & 1.244 &, 594 & .087 & $2.095^{*}$ \\
Task value & 1.282 &, 581 & .241 & $5.650^{*}$ \\
\hline
\end{tabular}

Note: Dependent Variable: BAT, $\mathrm{SE}=18.2118, \mathrm{R}=.406, \mathrm{R}^{2}=.165$, Adjusted $\mathrm{R}^{2}=.160,{ }^{*} \mathrm{p}<.05,{ }^{* *} \mathrm{p}<.01$. 


\section{Discussion}

According to the self-regulated learning literature three major cognitive strategies are heavily emphasized, which are rehearsal, elaboration, and organization, [41], [64]. These strategies are reported to be influencing students' cognitive engagement in the learning process, therefore, provide learner to achieve relatively higher, [62]. Results of the multiple regression analysis revealed that students' gender, use of elaboration as a deep learning strategy, task values, and self-efficacy beliefs were major predictors of their biology achievement. These findings are consistent with the previous studies in the related literature, [9], [19], [41], [44], [54], [59], [65], [67], [71]. In addition, results are in line with Eccles and Wigfield, [15] which stated that if individuals perceive a task as a joyful, useful or satisfactory task, they achieve higher on that task.

According to recent educational research, in order to explain students' higher academic achievement better, both the cognitive and affective variables were considerably took quite important focus, [41]. Based on this main idea, Pintrich and Schunk, [44] stated that task value beliefs are the strongest predictors of students' achievement. Results of the present study proved that 11 th grade students who valued Biology lessons more are more likely to achieve higher than others in Biology. This result is consistent with the findings of the related literature, [1], [11], [16], [19], [65], [71]. According to Pintrich and Schunk, [44] the reason why task values posses a close relationship with student achievement is its relationship with achievement related behaviors such as self-regulative abilities, motivation, achievement goals, choice, persistence and performance. Pintrich, [40] explained the cause of the dominance of this relationship as task values being the main determinant of judging a task is worth learning or not by helping to see its possible advantages or disadvantages, formerly. Due to all these reasons task values dominantly explained the majority of the variance in students' biology achievement in the present study.

A huge body of research also concluded that not only task values but also self-efficacy is a major factor explaining student achievemet, [1], [4], [5], [8], [24], [34], [37], [40], [41], [42], [44], [46], [49], [53], [56], [71], [74]. Results of the present study also indicated that 11 th grade students who posses more self-efficacy beliefs in Biology lessons are more likely to achieve higher than others in Biology. Pajares, [35] explained the reason that why self-efficacy influences students' achievement as due to its affect on students'patterns of thoughts and their affective responses. For Eggen and Kauchak, [17] described the mechanism as; higher self-efficacy is related to positive beliefs, which lead to more sincere intention, that causes more effort exerted, conclusively higher achievement. According to Zimmerman and Martinez-Pons [74] this is due to its improving influence on students' motivation. In addition, self-efficacy improves students' participation, autonomy and attendance; therefore, their achievement, [52]. These reasons might be valid for the present study to explain why students who beleived in their capability to successfully complete biology tasks were more successful in Biology than the students who did not believe in their ability to succeed.

Research also supported the idea that the effective use of learning strategies is another predictor of student better achievement levels, [7], [23], [41], [45], [71], [75]. Pintrich and Schunk, [45] stated that the factors explaining students' deeper understanding is not only his or her more effort that was exerted but also the deeper processing during learning. According to the results of this study, 11th grade students who use their elaboration strategies while learning Biology, as a higher order thinking skill, were more likely to achieve higher than others in Biology. This result is consistent with the related literature, [26], [38]. As a result, as students study by puting all the information together, relating the concepts to each other and their previous knowledge, and applying ideas in different classes and discussions, their Biology achievement increase. Because elaboration as a deep 
learning strategy requires students to constitute cognitive linkages between old and new knowledge, [1] elaboration provides learners to keeping the information in long term memory, [26], [64].

The present study also found out that 11 th grade male students tended to achieve higher than the females in biology. This result is consistent with the findings of Greenfield, [25] Lee and Burkham, [29] Martin et al., [31] Steinkamp and Maehr, [57] Tekkaya, Ozkan and Sungur [70], Willingham and Cole [69]. In the related literature, there are mixed results for the relationship between gender difference and science achievement. It was generally found that males outperform better than females in science; but the major factor causing this difference has still not clearly stated [22]. This may be due to females' tendency of posessing lower science self-efficacy than males, as reported by Calıskan, [10]. Tekkaya, Ozkan and Sungur [70] explained the reason why males outperform in science as, male students' perception of biology as an easier science topic to be studied. This difference was attempted to be explained by males' higher interest and self-efficacy in science, as dominantly and significantly affecting factors on students' academic achievement, [12], [36]. In the present study, males possessed slightly higher task values than the females, which was also found be the strongest predictor of students' biology achievement. Therefore, one of the possible reasons of this gender difference may be due to their higher task values obtained for this lesson. However, more research is needed to explore gender difference in achievement. On the other hand, other findings in the literature indicated a significant difference between males and females in science, [29] and biology, [34] achievement in favor of females, which contradicts with results of the current study. Lastly, there are also studies in the related literature finding no gender differences in learning and performance different from the findings of the present study, [32], [47], [60].

As well as significant variables, there are also non-significant results obtained in the present study. Rehearsal and organization learning strategies found to be non-significant to predict 11 th grade students' Biology achievement. However, the findings are inconsistent with the research studies stating that rehearsal, [62], [71] and organization [38], [64], [71] are related to students' higher achievement. The finding on rehearsal is consistent with research conducted by Parker, [38] in which rehearsal is assumed to be a surface learning strategy, therefore, found to be unrelated to meaningful learning. In other words, students who utilize rehearsal strategy read class notes over and over again without any connection among concepts and memorize important terms; therefore, they might not be successful in biology. The finding on organization is also inconsistent with several other studies, [38], [41], [61], [71]. One of the possible reasons of why organization was not found be a predictor variable in the present study may be its being more relative to storing information into memory effectively to remember, [13] rather than affecting achievement directly. This reason may also be due to the contradictory definition proposed by Schiefele, [48] as assuming organization as a surface learning strategy rather than a deep learning strategy defined by Entwistle, [18]. According to Al-Harthy and Was, [1] surface learning strategies are the ones that are negatively related with students achievement. Therefore, such like the German sample analyzed in Shiefele's (1991) study, the sample adopted in this study may perceive organization as a surface, rather than a deep learning strategy. For that reason, inconsistent result with the related literature might be gained through this scale.

The current study showed the significant contributing factors to the students' Biology achievement. Further research is also necessary to explore new predictors.

\section{References}

1. Al-Harthy, S. I., \& Was, C. A., Goals, efficacy and metacognitive self-regulation: A path analysis. International Journal of Education, 2, 1-20, (2010). 
2. Bandura. A.. Social Foundations of Thought and Action: A Social Cognitive Theory. Englewood Cliffs, NJ: Prentice-Hall, (1986).

3. Bandura. A., Human agency in social cognitive theory. American Psychologist, 44, 1175- 1184, (1989).

4. Bandura, A., Perceived self-efficacy in cognitive development and functioning. Educational Psvchologist, 28, 117-148, (1993).

5. Bandura. A.. Self-efficacv: The exercise of control. New York: Freeman. (1997).

6. Bandura, A., A social cognitive theory of personality. In L. Pervin \& O. John (Eds.), Handbook of personality (2nd ed., pp. 154-196). New York: Guilford Publications, (1999).

7. Berger, J. L., \& Karabenick, S. A., Motivation and students' use of learning strategies: Evidence of unidirectional influences in mathematics classrooms. Learning \& Instruction, 21(3), 416-428, (2010).

8. Britner, S. L., \& Pajares, F., Sources of science self-efficacy beliefs of middle school students. Journal of Research in Science Teaching 43(5), 485-499, (2006).

9. Cakıcı, Y., Arıcak, O.T., \& Ilgaz, G., Can "attitudes toward biology course" and "learning strategies" simultaneously predict achievement in biology? Eurasian Journal of Educational Research, 45, 31-48, (2011).

10. Caliskan, İ. S., The effect of inquiry-based chemistry course on students' understanding of atom concept, learning approaches, motivation, self-efficacy and epistemological beliefs. Ankara: Middle East Technical University, (2004).

11. DeBacker, T. K., \& Nelson, R. M., Variations on an expectancy-value model of motivation in science. Contemporary Educational Psychology, 24, 71-94, (1999).

12. DeBacker, T. K., \& Nelson, R. M., Motivation to learn science: Differences related to gender, class type, and ability. Journal of Educational Research, 93(4), 245- 255, (2000).

13. Dembo, M. H., \& Eaton, M. J., Self-regulation of academic learning in middle schools. The Elemantry School Journal, 100 (5), 473-490, (2000).

14. Eccles J. S., Adler, T. F., Futterman, R., Goff, S. B., Kaczala, C. M., Meece, J. L., \& Midgley, C., Expectancies, values, and academic behaviors. In J. T. Spence (Ed.), Achievement and achievement motivation (pp. 75-146). San Francisco, CA: W. H. Freeman, (1983).

15. Eccles, J. S., \& Wigfield, A., In the mind of the achiever: The structure of adolescents' academic achievement related-beliefs and self-perceptions. Personality and Social Psychology Bulletin, 21, 215-225, (1995).

16. Eccles, J. S., \& Wigfield, A., Motivational beliefs, values, and goals. Annual Review of Psychology, 53, 109-132, (2002).

17. Eggen, P., Kauchak, D., Educational Psychology: Windows on Classroom, Columbus Ohio: Merril, Prentice Hall, (1999).

18. Entwistle, N., "Motivational factors in students' approaches to learning", In Schmeck, R. R. (Ed.) Learning strategies and learning styles (pp. 21-49). New York: Plenum Press, (1988).

19. Fries, S., Schmid, S.. Dietz. F.. \& Hofer. M.. Conflicting values and their impact on learning. European Journal of Psvchologv of Education. 20, 259-274, (2005).

20. Gabel. D. L., Handbook of Research on Science Teaching and Learning A proiect of the National Science Teachers Association. New York: Macmillan Publishing Company, (1994).

21. Garcia, T., \& Pintrich, P. R., The effects of autonomy on motivation, use of learning strategies, and performance in the college classroom. Paper presented at the Annual Convention of the American Psychological Association, San Francisco, CA, (1991).

22. Garcia, T., \& Pintrich, P. R., Assesing Students' Motivation and Learning Strategies: The Motivated Strategies for Learning Questionnaire. Annual Meeting of the American Educational Research Association (pp. 18-22). San Francisco,CA: American Educational Research Association, (1995).

23. Garcia, T., \& Pintrich, P. R., The effects of autonomy on motivation and performance in the college classroom. Contemporarv Educational Psvchologv, 21, 477-486, (1996).

24. Graham. S., \& Weiner, B., Theories and principles of motivation. In Berliner, D.\& Calfee, R. C. (Eds.), Handbook of educational psychology (pp. 63-84). New York: Macmillan, (1996). 
25. Greenfield, T.A., An exploration of gender participation patterns in science competitions. Journal of Research in Science Teaching, 32(7), 735-748, (1995).

26. Johnsey, A., Morrison, G. R., \& Ross, S. M., Promoting generative learning in computer-based instruction through the use of elaboration strategies training. Contemporary Educational Psychology, 17, 125-135, (1992).

27. Kitsantas, A., Zimmerman, B.J., College students' homework and academic achievement: The mediating role of self-regulatory beliefs. Metacognition and Learning, 4(2), 1556-1623, (2009).

28. Landine, J., \& Stewart, J., Relationship between metacognition, motivation, locus of control, self-efficacy, and academic achievement. Canadian Journal of Counselling, 32(3), 200-212, (1998).

29. Lee, V.E. \& Burkam, D.T., Gender differences in middle grade science achievement: Subject domain, ability level, and course emphasis. Science Education, 80(6), 613-50, (1996).

30. Lenon, J. M., Self-Efficacy In. Rosen, J. A., Glennie, E. J., Dalton, B. W., Lennon, J. M., \& Bozick, R. N., Non-cognitive Skills in the Classroom: New Perspectives on Educational Research (s. 91-117). NC: Research Triangle International, (2010).

31. Martin, M.O., Mullis, I.V.S., and Foy, P., TIMSS 2007 International Science Report: Findings From IEA's Trends in International Mathematics and Science Study at the Eighth and Fourth Grades. Chestnut Hill, MA: Boston College. (2008).

32. Meece, J. L., Glienke, B. B., \& Burg, S., Gender and motivation. Journal of School Psvchologv. 44. 351-373. (2006).

33. Multon, K. D.. Brown, S. D., \& Lent, R. W., Relation of self-efficacy beliefs to academic outcomes: A meta-analytic investigation. Journal of Counseling Psychology, 38, 30-38, (1991).

34. Ozkan, S., The roles of motivational beliefs and learning styles on tenth grade students' biology achievement. Ankara: Middle East Technical University, (2003).

35. Pajares, F., Assessing self-efficacy beliefs and academic outcomes: The case for specificity and correspondence. Paper presented at the Annual Meeting of the American Educational Research Association, New York, (1996).

36. Pajares, F., Overview of social cognitive theory and of self-efficacy. Retrieved May 11, 2010, from http://www.emory.edu/EDUCATION/mfp/eff.html, (2002).

37. Pajares, F., Self-efficacy beliefs, motivation, and achievement in writing: A review of the literature. Reading and Writing Quarterly, 19(2), 139-158, (2003).

38. Parker, J. C., Gender Differences in the Motivation to Learn. Evergreen: Evergreen State College, (2007).

39. Pintrich, P., Understanding self-regulated learning. In Pintrich, P. (Ed.), Understanding Self-Regulated Learning. San Francisco, CA: Jossey-Bass., (1995).

40. Pintrich, P. R., Motivational beliefs as resources for and constrains on conceptual change. In: Schnotz,W., Vosniadou, S. \& Carretero, M. (Eds). New perspectives on conceptual change (pp. 33-50). Oxford: Elsevier, (1999).

41. Pintrich, P.R. \& De Groot E., Motivational and self-regulated learning components of classroom academic performance. Journal of Educational Psychology, 82(1), pp. 3350, (1990).

42. Pintrich, P. R., \& Schunk, D. H., Motivation in education: Theory, research, and applications. Englewood Cliffs, NJ: Prentice Hall, (1995).

43. Pintrich, P. R., \& Schunk, D. H., Motivation in education: Theory, research, and applications. Englewood Cliffs, NJ: Merrill/Prentice Hall, (1996).

44. Pintrich, P. R., \& Schunk. D. H.. Motivation in education: Theory, research, and applications. Pearson education. NJ: Merrill Prentice Hall. (2002).

45. Pintrich, P.R.. Smith. D.A.F., Garcia. T. \& McKeachie, W.J., A Manual for the Use of the Motivated Strategies for Learning. Michigan: School of Education Building, The University of Michigan. ERIC database number: ED338122. (1991).

46. Robbins, S. B., Lauver, K., Le, H., Davis, D., Langlev, R., \& Carlstrom. A., Do psvchosocial and study factors predict college outcomes? Psychological Bulletin, 130 (2), 261-288, (2004).

47. Rusillo, M. T. ve Arias, P. F., Gender differences in academic motivation of secondary school students. Journal of Educational Psychology. 2(1), 97-112, (2004). 
48. Schiefele, U., Interest, learning, and motivation. Educational Psychologist, 26, 299324. (1991).

49. Schunk, D. H., Self-efficacy and academic motivation. Educational Psychologist, 26. 207-232. (1991).

50. Schunk. D. H., Learning Theories: An Educational Perspective. Upper Sadddle River, NJ: Pearson Merill Prentice Hall Inc., (2008).

51. Schunk, D. H., \& Hanson. A. R.. Influence of peer-model attributes on children's beliefs and learning. Journal of Educational Psychology, 81, 431-434, (1989).

52. Schunk, D. H., \& Pajares, F., The Development of Academic Self-Efficacy. In Wigfield, A. \& Eccles, J. (Eds.), Development of Achievement Motivation. San Diego: American Press., (2001).

53. Schunk, D. H., \& Zimmerman, B. J., Self-regulation of learning and performance. Mahwah, NJ: Erlbaum, (1994).

54. Senay, A., The contribution of chemistry self-efficacy and goal orientations to eleventh grade students' chemistry achievement. Ankara: Middle East Technical Univetsity, (2010).

55. Shaughnessv, M. F., An interview with Anita Woolfolk: The educational psychology of teacher efficacy. Educational Psychology Review, 16(2), 153-176, (2004).

56. Singh, K., Granville, M., \& Dika, S., Mathematics and science achievement: Effects of motivation, interest, and academic engagement. The Journal of Education Research, 95(6), 323-332, (2002).

57. Steinkamp, W.M. \& Maehr, L.M., Affect, ability and science achievement. A quantative synthesis of correlational research. Review of Educational Research, 53 (3), 269-396, (1983).

58. Sungur, S., The implementation of problem-based learning in secondary school biology courses. Ankara: Middle East Technical University, (2004).

59. Sungur, S., Contribution of motivational beliefs and metacognition to students' performance under consequential and nonconsequential test conditions. Educational Research and Evaluation, 13(2), 127-142, (2007).

60. Sungur, S., \& Tekkaya C., Student's achievement in human circulatory system unit: The effect of resoning ability and gender. Journal of Science Education and Technology, 12 (1), 59-64, (2003).

61. Sungur, S., \& Tekkaya, C., Effects of problem based learning and traditional instruction on self-regulated learning. Journal of Educational Research, 99, 307-317, (2006).

62. Tassone. A.. The Explicit Use Of Performance Expectancv As A Function Of SelfRegulated Learning. Thunder Bav. Ontario: Lakehead Universitv. (2001).

63. Tschannen-Moran, M.. Woolfolk Hoy, A.. \& Hov, W. K.. Teacher efficacy: Its meaning and measure. Review of Educational Research. 68, 202-248, (1998).

64. Weinstein. C.E.. \& Maver. R.E.. The Teaching of Learning Strategies. In Wittrock. M. (Ed.). Handbook of research on teaching (pp. 315-327). New York, NY: Macmillan, (1986).

65. Wigfield, A., Expectancy-value theory of achievement motivation: A developmental perspective. Educational Psychology Review, 6(1), 49-78, (1994).

66. Wigfield, A., \& Eccles, J., The development of achievement task values: A theoretical analysis. Developmental Review, 12, 265-310, (1992).

67. Wigfield, A., \& Eccles, J. S., Expectancy-value theory of achievement motivation. Contemporary Educational Psychology, 25,68-81, (2000).

68. Wigfield, A., \& Eccles, J. S., The development of competence beliefs, expectancies of success, and achievement values from childhood through adolescence. In Wigfield, A. \& Eccles, J. S. (Eds.), Development of achievement motivation (pp. 91-120). San Diego, CA: Academic Press, (2002).

69. Willingham, W.W. \& Cole, N.S., Research on gender differences. In Willingham, W.W., \& Cole, N.S. (Eds.) Gender and Fair Assessment .NJ: Lawrence Erlbaum, (1997).

70. Yenilmez, A., Sungur, S., \& Tekkaya, C., Students' achievement in relation to reasoning ability, prior knowledge and gender. Research in Science \& Technological Education, 24 (1), 129-138, (2006). 
71. Yumusak, N., Predicting academic achievement with cognitive and motivational variables. Ankara: Middle East Technical University, (2006).

72. Yumusak, N., Sungur, S. and Çakıroglu J., Turkish high school students' biology achievement in relation to academic self-regulation. Educational Research and Evaluation, 13, 53-69, (2007).

73. Zimmerman, B.J., \& Bandura, A., Impact of self-regulatory influences on writing course attainment. American Educational Research Journal, 31, 845-862, (1994).

74. Zimmerman, B. J., Bandura, A., \& Martinez-Pons, M., Self-motivation for academic attainment: The role of self-efficacy beliefs and personal goal setting. American Educational Research Journal, 29, 663-676, (1992).

75. Zimmerman, B. J., \& Martinez Pons, M., Student differences in self-regulated learning: Relating grade, sex, and giftedness to self-efficacy and strategy use. Journal of Educational Psychology, 82(1), 51-59, (1990). 